Jurnal Professional FIS UNIVED Vol. 2 No.2 Desember 2015

\title{
IMPLEMENTASI KEBIJAKAN PEMBANGUNAN DAERAH PROVINSI BENGKULU BERDASARKAN ILMU PENGETAHUAN DAN TEKNOLOGI
}

\author{
Oleh:
}

\section{EVI LORITA}

\section{Dosen Prodi Administrasi Publik Fakultas Ilmu-Ilmu Sosial UNIVED Bengkulu}

\begin{abstract}
To achieve national aspirations to protect the whole Indonesian and the entire country of Indonesia, promote the commonweal, and educate the nation, the unitary state of Indonesia is divided into small government that has freedom to run the regional autonomy, including in the development of science and technology. Unfortunately, the development of science and technology has not run optimally, as happened in Bengkulu province. This research was a qualitative descriptive study which wanted to see the agenda of Bengkulu's Government in relation to regional policy framework for science and technology. Data were collected through interviews, observation and documentation. Data was analyzed by using qualitative data analysis Spradley models which was brought into line to the data analysis techniques in the research stage. The results showed that the regional development of science and technology policy for Bengkulu Province has two agenda namely science and technology to pave the backwardness and science and technology for prosperity. Those agendas were focused on the field of food security, energy, technology and transportation management, information and communication technology, security and defense technology, medical technology and medicine, and technology management of natural resources and the environment.
\end{abstract}

Keywords: Autonomy, National Aspirations, Science And Technology Development, Indonesia

\section{PENDAHULUAN}

Sebagai salah satu negara berkembang, Republik Indonesia saat ini tengah gencar-gencarnya melaksanakan pembangunan di segala bidang dalam rangka mewujudkan cita-cita nasional yaitu untuk melindungi segenap bangsa Indonesia dan seluruh tumpah darah Indonesia, memajukan kesejahteraan umum, mencerdaskan kehidupan bangsa dan ikut melaksanakan ketertiban dunia yang berdasarkan perdamaian abadi dan keadilan sosial, sesuai dengan yang disebut dalam Pembukaan Undang-Undang Dasar Negara Republik Indonesia Tahun 1945. UUD 1945 menyatakan bahwa Negara Kesatuan Republik Indonesia dibagi atas daerahdaerah Provinsi, dan daerah Provinsi itu dibagi atas Kabupaten dan Kota. Tiap- tiap
Provinsi, Kabupaten, dan Kota itu mempunyai Pemerintah Daerah yang diatur undang-undang. Hal ini memberikan keleluasaan kepada daerah untuk menjalankan Otonomi Daerah. Dalam hal ini Pemerintah Daerah dipandang sebagai mitra kerja yang terkait karena konsensus yang disepakati bersama dan diakui adil oleh masyarakatnya. Otonomi Daerah merupakan amanat rakyat yang diharapkan akan menjadi persyaratan bagi terciptanya upaya pembangunan yang lebih adil, demokratis dan mengikutsertakan peran serta aktif masyarakat disegala tingkatan dalam segala aspek.

Prinsip-prinsip yang diatur dalam Pasal 18 UUD 1945 setelah amandemen mengatur tentang prinsip-prinsip otonomi daerah, diantaranya adalah prinsip mengatur 
dan mengurus sendiri urusan pemerintah menurut asas otonomi dan tugas pembantuan, prinsip menjalankan otonomi seluas-luasnya, prinsip kekhususan dan keragaman daerah, prinsip mengakui dan menghormati kesatuan masyarakat hukum adat beserta hak tradisionalnya, prinsip mengakui dan menghormati Pemerintahan Daerah yang bersifat khusus dan istimewa, prinsip badan perwakilan dipilih langsung oleh suatu pemilihan umum. Sedangkan Undang-Undang Nomor 32 Tahun 2004 tentang Pemerintahan Daerah, menyatakan bahwa Otonomi Daerah adalah hak, wewenang dan kewajiban daerah otonom untuk mengatur dan mengurus sendiri urusan pemerintah dan kepentingan masyarakat setempat sesuai dengan peraturan perundang- undangan.

Keberhasilan pelaksanaan otonomi daerah akan dievaluasi oleh Pemerintah Pusat pada tahun 2013 dengan mengacu pada tiga indikator umum, yakni peningkatan kesejahteraan masyarakat, peningkatan pelayanan publik, dan peningkatan daya saing daerah. Ketiga indikator tersebut merupakan kontribusi daerah dalam upaya mewujudkan Indonesia yang mandiri, maju, adil dan makmur, sebagaimana tercantum dalam visi rencana pembangunan jangka panjang nasional (RPJPN) tahun 2005-2025. Oleh sebab itu, pemerintah suatu daerah harus berkomitmen untuk membangun kemandirian daerahnya dalam mewujudkan kehidupan yang sejajar dengan daerah-daerah lain di Indonesia yang telah maju.

Pembangunan IPTEK sebagai bagian integral pembangunan daerah harus ditujukan untuk menjadi landasan kemajuan daerah dan kesejahteraan masyarakat secara berkelanjutan. Kunci utama perwujudan ketiga indikator diatas adalah tersedianya strategi yang mengutamakan penciptaan keunggulan kompetitif melalui peningkatan nilai tambah yang tinggi dalam pengelolaan sumberdaya alam dan didukung oleh tersedianya infrastruktur yang memadai dan sumberdaya manusia yang berkualitas. Hal ini hanya dapat terwujud apabila suatu daerah mampu mengembangkan inovasi untuk kemajuan dan kesejahteraan.

Konsep sistem inovasi yang pada awalnya terfokus pada tujuan ekonomi seperti pertumbuhan produktivitas, peningkatan daya saing dan perluasan bisnis, saat ini berkembang dan menjangkau tujuan non-ekonomi seperti penyediaan layanan kesehatan, ketahanan pangan, penyediaan air bersih, keberlanjutan lingkungan dan lain-lain. Dalam hal ini, pelaku inovasi berperan dalam penyelesaian masalah yang ada di masyarakat. Untuk itu, pelaku inovasi perlu mempelajari proses pengambilan keputusan pada masingmasing tingkatan, baik lokal, regional, nasional maupun global, agar dapat menjamin terjadinya inovasi yang berkelanjutan.

Pemerintah daerah harus menyediakan rumusan kebijakan strategis agar proses inovasi dapat berjalan. Pada skala nasional, pemerintah telah memfasilitasi upaya pengembangan inovasi dengan mengeluarkan kebijakan strategis pembangunan nasional IPTEK (disingkat JAKSTRANAS IPTEK) Tahun 2010-2014 melalui Keputusan Menteri Riset dan Teknologi Nomor 193/M/Kp/IV/2010 Tahun 2010. Dokumen JAKSTRANAS IPTEK tersebut berisi arah, prioritas utama, dan kerangka kebijakan pembangunan nasional di bidang ilmu pengetahuan dan teknologi. Selanjutnya, JAKSTRANAS IPTEK digunakan sebagai acuan dalam menyusun Kebijakan Strategis Pembangunan Daerah Ilmu Pengetahuan dan Teknologi (disingkat JAKSTRADA IPTEK) dan Agenda Riset Daerah (disingkat ARD). 
Pembangunan IPTEK di Provinsi Bengkulu sejauh ini masih sangat terbatas yang dicirikan oleh masih minimnya sumberdaya IPTEK yang ada. Sumberdaya IPTEK seperti sarana-prasarana Litbang dan sarana IPTEK lainnya masih belum banyak ditemui di wilayah Provinsi Bengkulu. Akses masyarakat terhadap IPTEK hanya bisa dilakukan secara insedentil melalui aktivitas yang dilakukan oleh lembaga penghasil IPTEK seperti Litbang dan Perguruan Tinggi.

Padahal masyarakat membutuhkan akses yang kontiniu dan tersedia setiap saat. Kedepan, perlu dikembangkan saranaprasarana Litbang seperti Pusat IPTEK (Science Center), sarana pendidikan luar sekolah yang dipadukan dengan unsur hiburan untuk memperkenalkan IPTEK kepada masyarakat seperti Pusat Peraga IPTEK atau Taman Teknologi, sumberdaya manusia (SDM) IPTEK di berbagai lembaga Litbang daerah yang ditunjukkan antara lain dengan jumlah SDM yang berpendidikan $\mathrm{S} 1, \mathrm{~S} 2$ dan S3.

Terhambatnya pembangunan IPTEK di daerah dapat pula disebabkan oleh belum berkembangnya budaya IPTEK di Provinsi Bengkulu. Ketertarikan masyarakat terhadap IPTEK masih didominasi oleh kalangan pelajar dan mahasiswa, belum menjangkau masyarakat secara umum. Hal ini disebabkan karena belum optimalnya mekanisme intermediasi IPTEK di Provinsi Bengkulu. Pada tingkat nasional, beberapa lembaga telah berfungsi sebagai lembaga intermediasi IPTEK, seperti Business Innovation Center (BIC), Business Technology Center (BTC), dan beberapa unit kerja yang ada di lembaga Litbang seperti Pusat Inovasi-LIPI, Pusat Kemitraan Nuklir-BATAN, dan Balai Inkubator Teknologi-BPPT.

Kondisi berikutnya yang dihadapi dalam pembangunan IPTEK Provinsi Bengkulu adalah belum terkaitnya kegiatan riset dengan kebutuhan nyata. Sebagai contoh, salah satu ciri kemajuan ekonomi suatu negara dan daerah adalah tingginya ketergantungan pembangunan ekonomi terhadap inovasi. Ketergantungan pada inovasi yang demikian belum banyak ditemui dalam pembangunan di Provinsi Bengkulu bahkan di Indonesia. Rendahnya kontribusi IPTEK terhadap ekonomi Provinsi Bengkulu diperkirakan terkait dengan tiga hal: (i) masih lemahnya sisi penghasil IPTEK, (ii) masih lemahnya sisi pengguna IPTEK, dan (iii) masih lemahnya interaksi antara penghasil dan pengguna IPTEK.

Produk-produk IPTEK di Provinsi Bengkulu masih rendah akibat belum optimalnya kelembagaan Litbang dan Perguruan Tinggi dalam menghasilkan IPTEK. Aktivitas riset di perguruan tinggi, misalnya masih terkendala dana karena hanya bergantung pada anggaran yang disediakan pemerintah pusat. Padahal, kegiatan riset tersebut diharapkan dapat menghasilkan publikasi pada skala nasional maupun internasional. Kontribusi publikasi ilmiah internasional dan nasional diharapkan datang dari perguruan tinggi yang ada di provinsi Bengkulu baik perguruan tinggi negeri maupun perguruan tinggi swasta.

Untuk meningkatkan kontribusi IPTEK dalam pembangunan daerah diperlukan aliansi strategis antara penghasil dan pengguna IPTEK, baik aliansi horizontal di daerah maupun aliansi vertikal antara pusat dan daerah. Untuk itu perlu dibangun suatu jaringan yang saling memperkuat antara institusi penghasil IPTEK dan institusi pengguna IPTEK sehingga terjadi aliran sumberdaya IPTEK secara optimal. Jaringan yang demikian dapat diwujudkan melalui pembentukan suatu Sistem Inovasi Daerah (SIDa) yang merupakan bagian dari Sistem Inovasi 
Nasional (SINas) yang telah terlebih dahulu diluncurkan.

Tujuan disusunnya Kebijakan Strategis Pembangunan Daerah IPTEK Provinsi Bengkulu adalah untuk:

1. Memberikan arah dan kerangka kebijakan bagi pembangunan daerah IPTEK yang dilaksanakan oleh berbagai unsur kelembagaan IPTEK di Provinsi Bengkulu.

2. Menjadi sumber rujukan bagi para pemangku kepentingan (stakeholder) pembangunan daerah IPTEK di Provinsi Bengkulu.

$$
\text { Landasan hukum yang }
$$

digunakan dalam penyusunan

Kebijakan Strategis Pembangunan Daerah IPTEK Provinsi Bengkulu tahun 2011-2015 adalah:

1. Pasal 31 ayat 5 UUD 1945 amandemen ke-4 yang menyebutkan bahwa "Pemerintah memajukan ilmu pengetahuan dan teknologi dengan menjunjung tinggi nilai-nilai agama dan persatuan bangsa untuk memajukan peradaban serta kesejahteraan umat manusia".

2. Undang-undang Nomor 18 Tahun 2002 tentang Sistem Nasional Penelitian, Pengembangan dan Penerapan Ilmu Pengetahuan dan Teknologi (Sisnas P3 IPTEK) yang bertujuan untuk memperkuat daya dukung IPTEK dalam mempercepat pencapaian tujuan negara.

3. Undang-undang Nomor 17 Tahun 2007 tentang Rencana Pembangunan Jangka Panjang Nasional (RPJPN) 2005-2025 sebagai penjabaran dari tujuan negara ke dalam visi, misi, dan arah pembangunan nasional dalam kurun waktu 2005-2025.

4. Peraturan Presiden Nomor 5 Tahun 2010 tentang Rencana Pembangunan Jangka Menengah Nasional (RPJMN) tahun 2010-2014 yang merupakan penjabaran dari visi, misi dan program presiden ke dalam strategi pembangunan nasional, kebijakan umum, program prioritas, serta kerangka ekonomi makro yang mencakup gambaran perekonomian secara menyeluruh.

5. Instruksi Presiden Nomor 4 Tahun 2003 yang mengamanatkan untuk pengkoordinasian dalam perumusan dan pelaksanaan kebijakan strategis pembangunan nasional IPTEK, terutama dalam koordinasi antar instansi terkait.

6. Keputusan Menteri Riset dan Teknologi Nomor 193/M/Kp/IV/2010 Tahun 2010 tentang Kebijakan Strategis Pembangunan Nasional Ilmu Pengetahuan dan Teknologi Tahun 20102014 yang berisi arah, prioritas utama, dan kerangka kebijakan pembangunan nasional di bidang ilmu pengetahuan dan teknologi.

7. Buku Putih Penelitian, Pengembangan dan Penerapan IPTEK 2005-2025 Tahun 2006 yang memberikan landasan akademik terhadap 6 (enam) bidang fokus pembangunan IPTEK, berisi roadmap masing-masing bidang.

Berdasarkan latar belakang tersebut penulis tertarik melakukan penelitian dengan judul "Kebijakan Strategis Pembangunan Daerah Ilmu Pengetahuan dan Teknologi Provinsi Bengkulu". Adapun tujuan penelitian ini adalah: 1) Strategi Operasional (Kerangka Kebijakan) dan, 2) Prioritas Utama dan Fokus Pembangunan IPTEK.

\section{METODOLOGI PENELITIAN}

Tipe penelitian yang digunakan dalam penelitian ini adalah penelitian yang disajikan secara deskriptif kualitatif. Menurut Sugiyono (2012: 7-8) penelitian kualitatif adalah penelitian tentang riset yang bersifat deskriptif. Dalam penelitian ini peneliti menggunakan teknik pengumpulan data dengan Wawancara, 
Observasi dan Dokumentasi. Analisis data menggunakan analisis data kualitatif, maka dalam analisis data selama di lapangan peneliti menggunakan model Spradley, yaitu teknik analisa data yang disesuaikan dengan tahapan dalam penelitian.

\section{HASIL PENELITIAN DAN PEMBAHASAN \\ Strategi Operasional (Kerangka Kebijakan)}

Strategi pencapaian tujuan pembangunan daerah IPTEK Provinsi Bengkulu adalah dengan mengelompokkan ketujuh fokus pembangunan IPTEK menjadi dua agenda utama sesuai dengan visi dan misi. Pengelompokan fokus pembangunan tersebut adalah sebagai berikut:

1. IPTEK untuk meretas ketertinggalan, mencakup fokus pembangunan IPTEK sumber energi terbarukan, pengelolaan sumberdaya alam dan lingkungan, teknologi pertahanan dan keamanan, dan teknologi informasi dan komunikasi.

2. IPTEK untuk kesejahteraan, mencakup fokus pembangunan teknologi ketahanan pangan, teknologi manajemen transportasi, dan teknologi kesehatan dan obat-obatan.

Kerangka kebijakan pembangunan daerah IPTEK Provinsi Bengkulu untuk mendukung inovasi selanjutnya dapat diuraikan sebagai berikut:

\section{Agenda 1: IPTEK Untuk Meretas Ketertinggalan}

1. Pembangunan IPTEK sumber energi terbarukan. Indikator yang ingin dicapai adalah semua desa teraliri listrik, minimal 95\% rumah tangga menikmati layanan listrik, dan setiap desa memiliki minimal satu industri kerakyatan yang berbasis sumberdaya listrik. Capaian tersebut akan diwujudkan melalui inventarisasi sebaran lokasi kebutuhan listrik dan sumber listrik yang tersedia di setiap lokasi, serta melakukan studi kelayakan dan penyusunan detail engineering design (DED) listrik.

2. Pengelolaan sumberdaya alam dan lingkungan. Indikator capaian adalah stabilnya luas tutupan hutan tanpa terjadi alih fungsi lahan menjadi areal perkebunan, terpeliharanya kuantitas dan kualitas air, dan terpeliharanya kualitas udara. Capaian tersebut akan diwujudkan melalui riset pengendalian pencemaran dan perusakan lingkungan hidup, riset perlindungan dan konservasi sumberdaya alam, riset rehabilitas dan pemulihan cadangan sumberdaya alam, riset pengelolaan dan rehabilitasi ekosistem pesisir dan laut, dan riset pengembangan kinerja pengelolaan persampahan.

3. Pengembangan teknologi pertahanan dan keamanan. Indikator capaiannya adalah tersedianya informasi IPTEK untuk pembangunan pangkalan pertahanan di Pulau Enggano. Capaian ini akan diwujudkan melalui studi kelayakan dan analisis dampak pembangunan pangkalan pertahanan di Pulau Enggano.

4. Pengembangan teknologi informasi dan komunikasi. Indikator capaiannya adalah terbentuknya Sistem Informasi dan Komunikasi berbasis open source yang dapat diakses oleh semua lapisan masyarakat. Capaian ini akan diwujudkan melalui riset di bidang komunikasi, informasi dan media massa, fasilitasi teknologi informasi dan komunikasi, dan riset untuk pengembangan sistem komunikasi pedesaan.

\section{Agenda 2: IPTEK Untuk Kesejahteraan}

1. Pengembangan teknologi ketahanan pangan. Indikator capaian adalah tersedianya database daerah rawan pangan dan potensi produksi pangan, tersusunnya pola konsumsi dan suplai 
pangan, dan terbentuknya model desa mandiri pangan. Capaian tersebut akan diwujudkan melalui riset di bidang pemetaan daerah rawan dan potensi produksi pangan, kajian sistem suplaidemand pangan, revitalisasi nilai kearifan lokal, riset teknologi produksi dan pasca panen, dan penyusunan model desa mandiri pangan.

2. Pengembangan teknologi manajemen transportasi. Indikator capaian adalah tersedianya database sarana-prasarana transportasi, meningkatnya status jalan provinsi menjadi jalan negara (Manna-Pagar Alam-Lahat; BintuhanMuara Dua-Baturaja), dan tersusunnya rencana induk transportasi antar kabupaten dan antar provinsi. Capaian ini diwujudkan melalui riset pengembangan sistem manajemen transportasi darat (jalan produksi, jalan poros desa, jalan lintas kecamatan dan kabupaten/kota), riset pengembangan rencana induk transportasi penghubung kawasan barat dan timur Pulau Sumatera di Provinsi Bengkulu (feeder road dan rel kereta api), dan riset pengembangan pelabuhan nasional dan internasional (Pulau Baai dan Linau).

3. Pengembangan teknologi kesehatan dan obat-obatan. Indikator capaian adalah tersedianya IPTEK kesehatan yang aplikatif untuk peningkatan cakupan layanan kepada masyarakat. Capaian ini akan diwujudkan melalui riset, pengembangan, dan rekayasa IPTEK kesehatan untuk penyediaan obat yang terjangkau oleh seluruh masyarakat, pengembangan fitofarmaka, pengendalian penyakit melalui deteksi dini, dan peningkatan mutu layanan kesehatan.

Apabila kedua agenda di atas terealisasi maka indikator pembangunan secara keseluruhan adalah:
- Bengkulu bebas keterisolasian dalam bidang transportasi dan komunikasi.

- Pendapatan perkapita diatas US\$ 1 per hari.

- Angka kemiskinan kurang dari $15 \%$.

- Indeks pembangunan manusia diatas 75 .

\section{Prioritas Utama dan Fokus Pembangunan IPTEK}

Mengacu pada Kebijakan Strategis Pembangunan Nasional IPTEK, maka pembangunan IPTEK di Provinsi Bengkulu selama lima tahun kedepan ditujukan untuk mendukung bidang-bidang sebagai berikut:

1. Ketahanan pangan,

2. Energi,

3. Teknologi dan manajemen transportasi,

4. Teknologi informasi dan komunikasi,

5. Teknologi pertahanan dan keamanan

6. Teknologi kesehatan dan obat, dan

7. Teknologi pengelolaan sumberdaya alam dan lingkungan hidup

\section{PENUTUP}

\section{Kesimpulan}

1. Terdapat dua agenda dalam Kerangka kebijakan pembangunan daerah IPTEK Provinsi Bengkulu untuk mendukung inovasi, yaitu: (1) Agenda 1: IPTEK Untuk Meretas Ketertinggalan, dan (2) Agenda 2: IPTEK Untuk Kesejahteraan.

2. Pembangunan IPTEK di Provinsi Bengkulu selama lima tahun kedepan ditujukan untuk mendukung bidangbidang sebagai berikut:

1) Ketahanan pangan,

2) Energi,

3) Teknologi dan manajemen transportasi,

4) Teknologi informasi dan komunikasi,

5) Teknologi pertahanan dan keamanan

6) Teknologi kesehatan dan obat, dan

7) Teknologi pengelolaan sumberdaya alam dan lingkungan hidup 


\section{DAFTAR PUSTAKA}

Abidin, Said Zainal. (2006). "Kebijakan Publik (Cetakan Ketiga)". Jakarta: Suara Bebas.

Ali, Faried. (2011). "Teori dan Konsep Administrasi: Dari Pemikiran Paragdigmatik Menuju Redefinisi”. Jakarta: PT. Raja Grafindo Persada.

Alexander, Abe. (2001). "Perencanaan Daerah". Yogyakarta: Lapera Pustaka Utama.

Anonim, Undang-undang No.25 Tahun 2004 tentang Sistem Perencanaan Pembangunan Nasional (SPPN).

Budiman, Arief. (1995). "Teori Pembangunan Dunia Ketiga” Jakarta: Gramedia Pustaka Utama.

Dewan Riset Daerah Provinsi Bengkulu. (2010). Kebijakan Strategis Pembangunan Daerah Ilmu Pengetahuan Dan Teknologi (Jakstrada-Iptek) Tahun 2011-2015. Bengkulu.

Dunn, William N. (2000). "Pengantar Analisis Kebijakan Publik, Edisi Kedua". Yogyakarta: Gadjah Mada University Press.

Dwidjowijoto, Riant Nugroho. (2003). "Kebijakan Publik: Formulasi, Implementasi dan Evaluasi”. Jakarta: PT. Elex Media Komputindo.

Nazir, Moh. (2003). "Metode Penelitian". Jakarta: Ghalia Indonesia.

Parsons, Wayne. (2008). "Public Policy: Pengantar Teori dan Praktik Analisis Kebijakan (Edisi 1, Cetakan Ketiga”). Jakarta: Kencana.
Simin, Widiastuti Tri Rini. (2005). "Perencanaan Pembangunan Partisipatif Daerah di Wilayah BARLINGMASCAKEB". Jurnal Visi Publik Vol 2 No.1. Purwokerto: FISIP UNSOED.

Soetrisno, Loekman. (1995). "Мепијu Masyarakat Partisipatif". Yogyakarta: Kanisius.

Sugiyono. (2007). "Memahami Penelitian Kualitatif'. Bandung: Alfabeta

Suharto, Edi. (2012). "Analisis Kebjakan Publik (Panduan Praktis Mengkaji Masalah dan Kebijakan Sosial)". Bandung: CV. Alfabeta

Suparjan, Suyatno Hempri. (2003). "Pengembangan Masyarakat dari Pembangunan sampai Pemberdayaan". Yogyakarta: Aditya Media

Sutopo, HB. (1998). "Pengantar Penelitian Kualitatif: Dasar-dasar Teori dan Praktis". Surakarta: Pusat Penelitian UNS.

Syafiie, Inu Kencana. (2003). "System Administrasi Negara Republik Indonesia". Bandung: Bumi Aksara.

Usman, Husain dan Purnomo Setiady Akbar. (2006). "Metodologi Penelitian Sosial". Jakarta: Bumi Aksara.

Wahab, Solichin Abdul. (1991). "Analisis Kebijakan Dari Formulasi Ke Implementasi Kebijaksanaan Negara". Jakarta: Bumi Aksara

Winarno, Budi. Teori dan Proses Kebijakan Publik. Yogyakarta: Media Pressindo. 